\title{
Effect of Pseudomonas fluorescens proteases on the quality of Cheddar cheese
}

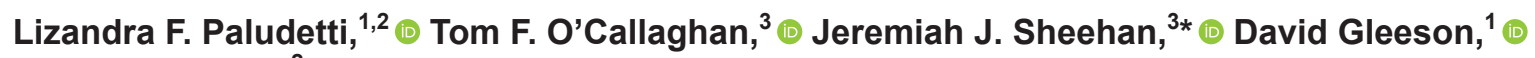 \\ and Alan L. Kelly ${ }^{2}$ (D) \\ ${ }^{1}$ Teagasc Animal \& Grassland Research and Innovation Centre, Moorepark, Fermoy, P61 C996 County Cork, Ireland \\ ${ }^{2}$ School of Food and Nutritional Sciences, University College Cork, T12 K8AF County Cork, Ireland \\ ${ }^{3}$ Teagasc Food Research Centre, Moorepark, Fermoy, P61 C996 County Cork, Ireland
}

\section{ABSTRACT}

The objective of this study was to investigate the effect of adding different levels of a thermoresistant protease produced by a Pseudomonas fluorescens strain to milk on the manufacture and quality of Cheddar cheese. Fresh raw milk was collected, standardized, and pasteurized at $72^{\circ} \mathrm{C}$ for $15 \mathrm{~s}$, and the enzyme was added to give a protease activity of 0.15 or $0.60 \mathrm{U} / \mathrm{L}$ (treatments $\mathrm{P} 1$ and $\mathrm{P} 4$, respectively), while one sample had no enzyme added (control). Milk was stored at $4^{\circ} \mathrm{C}$ for $48 \mathrm{~h}$ and Cheddar cheese was manufactured after 0 and $48 \mathrm{~h}$ of storage. Results indicated that the protease was active in milk during $48 \mathrm{~h}$ of storage; however, its effect on milk composition was minimal. The protein that was preferentially hydrolyzed by the protease over storage was $\beta$-casein, followed by $\kappa$-casein. The mean cheese yield and recovery of fat and protein obtained for all cheeses were not affected by protease activity. The protease showed low activity during cheese manufacture, possibly because of unfavorable conditions, including low $\mathrm{pH}$. One of the factors that might have influenced protease activity was the $\mathrm{pH}$ of the curd (approximately 6.55 after acidification and 5.35 at milling), which was lower than that at which the enzyme would have optimum activity (pH 7 to 9). Consequently, the composition, $\mathrm{pH}$, patterns of proteolysis, and hardness of all cheeses produced were similar and in accordance with values expected for that type of cheese, independently of the protease activity level. However, slight increases in proteolysis were observed in $\mathrm{P} 4$ cheeses and produced using milk stored for $48 \mathrm{~h}$. Both the P1 and P4 cheeses had higher concentrations of free amino acids (FAA) compared with the control, whereas urea-PAGE electrophoretograms indicated a greater breakdown of caseins in the $\mathrm{P} 4$ cheese samples, which may be related

Received December 11, 2019.

Accepted April 10, 2020.

*Corresponding author: Diarmuid.Sheehan@teagasc.ie to possible increases in numbers of proteolytic bacteria in milk during storage. Therefore, the thermoresistant psychrotrophic bacterial protease(s) tested in this study may affect the manufacture or quality of Cheddar cheese during ripening to a relatively limited extent. However, controlling initial levels of proteolytic bacteria in raw milk remains essential, because proteolysis affects the development of flavor and texture in cheese. Key words: Pseudomonas fluorescens, psychrotrophic bacteria, thermoresistant protease, Cheddar cheese

\section{INTRODUCTION}

Worldwide production of cheese is approximately 19 $\times 10^{6}$ tonnes per year, and production has increased at an average annual rate of approximately $4 \%$ over the past $30 \mathrm{yr}$ (Fox et al., 2017). The increase in cheese consumption could be due to the positive dietary image of the product, convenience, and flexibility of use, as well as the great diversity of flavors and textures. Cheddar cheese is one of the most important cheese varieties worldwide and is one of the main dairy products exported by Ireland and the United Kingdom (Fox et al., 2017).

The quality of milk supplied for cheese manufacture is one of the main factors affecting the quality of the final product. The microbiota of raw milk during cold storage is mainly composed of gram-negative and gram-positive psychrotrophic bacteria. The most common psychrotrophs identified in raw milk belong to the genus Pseudomonas (Ercolini et al., 2009; Ribeiro Júnior et al., 2018). Most lipases and proteases produced by this bacterial species are thermoresistant and can withstand heating to $100^{\circ} \mathrm{C}$ for $30 \mathrm{~min}$. Those enzymes are produced when psychrotrophic bacterial counts $(\mathbf{P B C})$ are $>6.0$ or $7.0 \log _{10} \mathrm{cfu} / \mathrm{mL}$ and are not eliminated after heat treatment, affecting the quality of cheese products (Fox, 1989; Fox et al., 2017). According to Sørhaug and Stepaniak (1997), PBC between 6.5 and $7.5 \log _{10} \mathrm{cfu} / \mathrm{mL}$ can cause rancidity in 
hard cheeses, whereas counts between 7.5 and $8.3 \log _{10}$ $\mathrm{cfu} / \mathrm{mL}$ can cause off-flavors (i.e., rancidity and soapy taste) and reduced cheese yield. Most psychrotrophic proteases are metalloproteases, which preferentially hydrolyze $\kappa-\mathrm{CN}$, then $\beta-\mathrm{CN}$, and finally $\alpha_{\mathrm{S}_{1}} \mathrm{CN}$, potentially causing reductions in cheese yield (Decimo et al., 2014). Boulares et al. (2011) and Mankai et al. (2012) observed decreases in cheese yield that were associated with the loss of protein into whey due to the activity of proteases produced by psychrotrophic bacteria. Even though certain products of microbial proteolysis can be undesirable in raw milk during storage and cheese manufacture, specific starter cultures are added into milk to promote proteolysis during ripening for the development of texture and flavor in different cheese varieties.

Several studies have investigated the effects of thermoresistant psychrotrophic bacterial proteases on UHT milk, determined the genetic characteristics of protease produced by Pseudomonas, and assessed their proteolytic activity (Marchand et al., 2009; Matéos et al., 2015; Caldera et al., 2016). Tye et al. (1988) evaluated the effects of a thermoresistant protease produced by a Pseudomonas fluorescens strain on the composition and sensorial characteristics of Cheddar cheese. However, the dynamics and activity of those proteases during the manufacturing process of a range of other dairy products, their effect on raw milk, and consequent implications for the quality of the final product require further investigations. Cheeses can vary greatly in relation to their processing parameters, $\mathrm{pH}$, and microbiota, which can determine the type and activity of proteases in those products. Therefore, the aim of this study was to investigate the effect of different activity levels of a thermoresistant protease, produced by a $P$. fluorescens strain, on the manufacture, proteolysis, and quality of Cheddar cheese.

\section{MATERIALS AND METHODS}

\section{Culture of Pseudomonas fluorescens and Protease Extraction}

Pseudomonas fluorescens ATCC 17556 was grown in nutrient broth (meat extract $3 \mathrm{~g} / \mathrm{L}$, meat peptone 5 $\mathrm{g} / \mathrm{L}$; Sigma Aldrich, Dublin, Ireland) for $72 \mathrm{~h}$ at $26^{\circ} \mathrm{C}$ with stirring at $90 \mathrm{rpm}$. Then, $1 \mathrm{~mL}$ of the inoculated nutrient broth was spread plated on blood agar plates (horse blood agar, 7\% concentration, Base No. 2; Oxoid, Basingstoke, UK) and plates were incubated for 24 $\mathrm{h}$ at $26^{\circ} \mathrm{C}$. Bacterial colonies were transferred to 100 $\mathrm{mL}$ of sterilized reconstituted skim milk powder $(10 \%$ $\mathrm{wt} / \mathrm{vol}$ ). The inoculated reconstituted skim milk bottles were incubated for $120 \mathrm{~h}$ at $10^{\circ} \mathrm{C}$ with stirring at 90 $\mathrm{rpm}$. Then, the bottles were centrifuged at $20,000 \times g$ at $25^{\circ} \mathrm{C}$ for $30 \mathrm{~min}$, and the supernatant containing protease was collected. The same supernatant containing the protease was used in a previous study conducted by the authors, and it was determined that the protease was thermoresistant, because it remained active in the supernatant after being heated at $72^{\circ} \mathrm{C}$ for $15 \mathrm{~s}$ (temperature applied during pasteurization; Paludetti et al., 2020).

\section{Milk Collection}

At the Teagasc Animal and Grassland Research and Innovation Centre (Moorepark, Cork, Ireland), springcalving cows were milked in a 30 -unit side-by-side milking parlor. The milking equipment used and processes for udder preparation and sanitation were as described by Paludetti et al. (2018a). This experiment was repeated in triplicate over a 3 -wk period. During that period, fresh raw milk was collected once per week and directly transferred from the milking machine line to 3 sanitized containers. The containers were transported to the Biofunctional Food Engineering facility at the Teagasc Food Research Centre (Moorepark, Cork, Ireland), where milk was standardized, pasteurized, and used for the production of Cheddar cheese.

\section{Milk Standardization, Pasteurization, and Inoculation}

Raw milk was skimmed using a tabletop cream separator (Milky FJ 130 ERR, Janschitz GmbH, Althofen, Austria), and the fat and protein contents in the separated cream and skim milk were measured by infrared absorption spectroscopy (MilkoScan FT6000, Foss Ireland Ltd., Dublin, Ireland). Pearson's square calculations were used to determine the amounts of skim milk and cream that should be mixed to achieve a protein-to-fat ratio of 0.95:1.00. The standardized milk was pasteurized at $72^{\circ} \mathrm{C}$ at a flow rate of $2 \mathrm{~L} / \mathrm{min}$ with a holding time of $15 \mathrm{~s}$ using a Microthermics Lab heat exchanger (MicroThermics, Raleigh, NC).

The pasteurized milk was divided into 3 sanitized containers (40 L/container). In a previous study, the activity of the protease in the supernatant was determined by an azocasein test $(0.030 \mathrm{U} / \mathrm{mL} \cdot \mathrm{min}$, Paludetti et al., 2020) and, based on that value, the milk containers had different amounts of supernatant added to obtain different levels of protease activity in the milk samples. One unit of protease activity (U) was defined as the amount of enzyme required to hydrolyze azocasein resulting in an increase of 1 unit of absorbance per $\mathrm{mL}$ of sample (supernatant) per minute (Leighton et al., 1973). Supernatant was not added to one milk container used as a control $(\mathbf{C})$, whereas 5 
and $20 \mathrm{~mL}$ of supernatant per $\mathrm{L}$ of milk were added to the other 2 containers, to obtain activity levels of 0.15 and $0.60 \mathrm{U} / \mathrm{L}(4 \times 0.15 \mathrm{U} / \mathrm{L})$, respectively (treatments $\mathbf{P} \mathbf{1}$ and $\mathbf{P} 4$, respectively). These concentrations were selected based on a previous study (Paludetti et al., 2020), in which milk samples containing those levels of protease activity coagulated after rennet addition, and therefore, Cheddar cheese manufacture would be possible. All milk containers were stored at $4^{\circ} \mathrm{C}$ for 48 $\mathrm{h}$, and Cheddar cheese was produced after 0 and $48 \mathrm{~h}$ of inoculation. The experimental design of this study is shown in Figure 1.

\section{Milk Composition}

After 0 and $48 \mathrm{~h}$ of storage, the composition of each milk was assessed. The nitrogen $(\% \mathrm{~N})$, noncasein nitrogen $(\% \mathbf{N C N})$ and NPN $(\% \mathrm{NPN})$ contents of the milk

\section{Milk Collection}
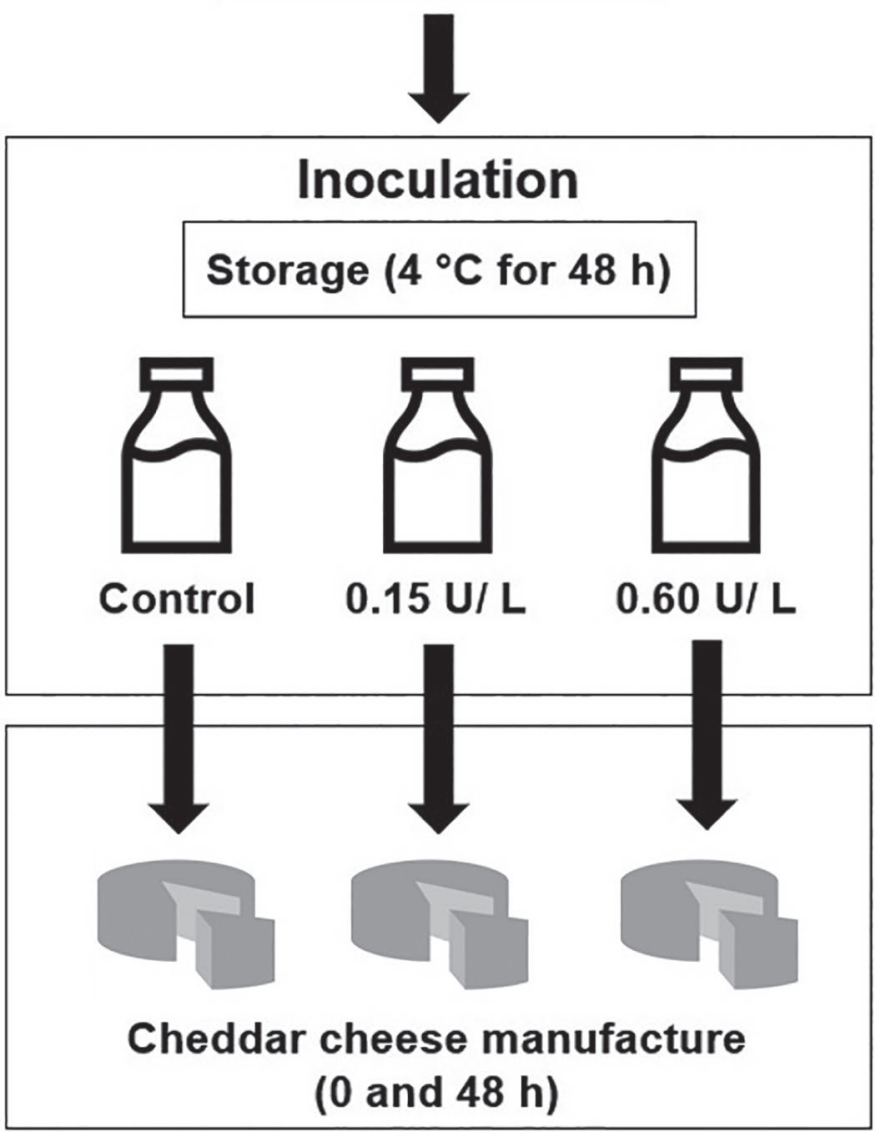

Figure 1. Experimental design showing process for production of cheeses made from milk inoculated with $0.15(\mathrm{P} 1)$ and $0.60(\mathrm{P} 4) \mathrm{U} / \mathrm{L}$ protease or not inoculated (control) and stored for 0 and $48 \mathrm{~h}$ before cheesemaking. samples were determined using the Kjeldahl method, as described in the methods IDF 20-3 (IDF, 2004a), 29-1 (IDF, 2004b), and 20-4 (IDF, 2001), respectively, using a Tecator Digestor Auto and Kjeltec 8400 distiller (Foss Electric, Hillerød, Denmark). Noncasein protein (\%NCP) was calculated by multiplying $\% \mathrm{NCN}$ by 6.38. The $\mathrm{pH}$ of milk was also measured after 0 and 48 $\mathrm{h}$ of storage, before cheese manufacture.

The casein and whey protein fractions $\left(\kappa-\mathrm{CN}, \alpha_{\mathrm{S}^{-}}\right.$ $\mathrm{CN}, \alpha_{\mathrm{S} 1}-\mathrm{CN}, \beta-\mathrm{CN}, \alpha-\mathrm{LA}, \beta-\mathrm{LG}$ A, $\beta$-LG B, and total casein) were identified and quantified (in triplicate) in the milk samples by HPLC as described by Paludetti et al. (2018b). Gradient elution and peak detection were performed according to the method of Mounsey and O'Kennedy (2009). The concentrations of each protein were determined by measurement of the peak areas with reference to standard of known concentrations.

\section{Microbiological Count in Milk Samples}

The total bacterial count (TBC) and PBC were assessed in all milk samples at 0 and $48 \mathrm{~h}$, after pasteurization and inoculation. Both bacterial counts were estimated using Petrifilm aerobic count plates (3M, Technopath, Tipperary, Ireland). Samples were incubated at $32^{\circ} \mathrm{C}$ for $48 \mathrm{~h}$ to determine $\mathrm{TBC}$, and samples were incubated at $7^{\circ} \mathrm{C}$ for $10 \mathrm{~d}$ to determine PBC (Laird et al., 2004). Those tests were performed according to the Standard Methods for the Examination of Dairy Products (Wehr and Frank, 2004).

\section{Cheddar Cheese Production}

After 0 and $48 \mathrm{~h}$ of inoculation and storage, milks with different protease activity levels were used to manufacture Cheddar cheese. During a 3 -wk period, 2 cheesemaking trials were undertaken in each week. During each 3-wk period, $10 \mathrm{~L}$ of each milk was transferred into jacketed, stainless steel cheese vats, which contained automated variable speed cutting and stirring equipment. The milks from different treatments were inoculated at $32^{\circ} \mathrm{C}$ with strains of lactic acid bacteria (Lactococcus lactis ssp. cremoris and Lactococcus lactis ssp. lactis; R-604, Chr. Hansen Ltd., Cork, Ireland). After 60 min, rennet (Chy-Max Plus, Chr. Hansen Ltd.), diluted in Milli-Q water (approximately $0.1 \%$, vol/vol), was added to each vat at a level of $2 \mathrm{~mL} / \mathrm{L}$.

Small-amplitude oscillatory rheometry (AR 2000ex, TA Instruments, New Castle, DE) was used to determine curd firmness (storage or elastic modulus, $\mathrm{G}^{\prime}$ ), by using a concentric-cylinder measuring geometry (cylindrical bob and cup). The dynamic changes in rheology during the coagulation process were monitored using a dynamic time sweep analysis, as described by Mateo et 
al. (2010) and Lamichhane et al. (2018), but at $32^{\circ} \mathrm{C}$. The gels were cut at a curd firmness of $35 \mathrm{~Pa}$.

The cut program of 3 min consisted of alternating between cutting (40 s) and healing (20 s). The curd/ whey mixture was stirred continuously for $15 \mathrm{~min}$ and then cooked; the temperature was increased at approximately $0.2^{\circ} \mathrm{C} / \mathrm{min}$ from 32 to $38^{\circ} \mathrm{C}$. At $\mathrm{pH} 6.15$, the whey was drained and the curds were retained in the vat to promote further syneresis. The curds were inverted every 15 min and $\mathrm{pH}$ was monitored over that period (cheddaring). At $\mathrm{pH} 5.30$, the curds were milled and salted (2.7\% salt, wt/wt of cheese). The curds from each vat were weighed and molded in $2 \times 500-\mathrm{g}$ molds, pressed at $150 \mathrm{kPa}$ overnight, weighed again, and vacuum-packed. The cheeses were stored at $4^{\circ} \mathrm{C}$ for $14 \mathrm{~d}$ and ripened at $8^{\circ} \mathrm{C}$ for $180 \mathrm{~d}$.

Cheese yield (Y\%) was calculated as the ratio between the weight of cheese produced $(\mathrm{g})$ to the weight of milk used (g) multiplied by 100. Moisture-adjusted yield was not calculated because the moisture contents of the cheeses was not significantly different. Fat and

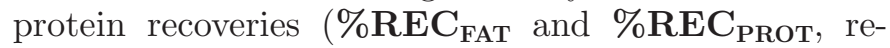
spectively) were calculated as the ratio of the weight (g) of the curd component (fat or protein) to the same component of milk (g) multiplied by 100 .

\section{Cheese and Whey Composition}

At $7 \mathrm{~d}$ after manufacture, the moisture (IDF, 1982), protein (IDF, 1993), salt (IDF, 1988), and fat contents of all cheeses were determined. The fat content was measured by nuclear magnetic resonance, using a CEM Smart Trac System method (Cartwright et al., 2005). Based on the content of those parameters, the contents of TS, salt-in-moisture $(\mathbf{S} / \mathbf{M})$, moisture in the nonfat substance (MNFS), and fat in dry matter (FDM) were calculated. The $\mathrm{pH}$ of the cheeses was monitored after $7,14,90$, and $180 \mathrm{~d}$ of ripening, by mixing $20 \mathrm{~g}$ of cheese with $12 \mathrm{~g}$ of deionized water (British Standards Institution, 1976). The fat and protein contents in whey were determined according to IDF standard methods 22 (IDF, 2008) and 20-3 (IDF, 2004a), respectively.

\section{Assessment of Proteolysis}

$p H$ 4.6-Soluble $N$ and Free Amino Acids. The $\mathrm{pH} 4.6$-soluble $\mathrm{N}$ (SN) fractions of the cheeses ripened for 14, 90 and $180 \mathrm{~d}$ (expressed as \% of total nitrogen, TN) were obtained as described by Fenelon and Guinee (2000). The nitrogen content of those fractions (pH 4.6-SN/TN) were determined in duplicate by the macro-Kjeldahl method (IDF, 1986). The levels of free amino acids (FAA) were measured as described by
Sheehan et al. (2007). Equal volumes of pH 4.6-SN and trichloroacetic acid $(240 \mathrm{~g} / \mathrm{L})$ were mixed to deproteinize the samples, and ion-exchange chromatography with post-column ninhydrin derivatization and visible colorimetric detection was used to separate the FAA.

Reversed-Phase HPLC. The peptide profiles of $\mathrm{pH}$ 4.6-soluble fractions were obtained by reversed-phase HPLC using an ultra-performance liquid chromatography system (UPLC) as described by McAuliffe (2017).

Urea-PAGE. Urea-PAGE was carried out on all cheeses after 14, 90, and $180 \mathrm{~d}$ of ripening. The analysis was performed using a Protean II xi cell vertical slab gel unit (Bio-Rad Laboratories Ltd., Hemel Hempstead, UK), using a separating and stacking gel system, as described by Sheehan and Guinee (2004). Sodium caseinate powder (Kerry Ingredients, Listowel, Ireland), which contained $\alpha_{\mathrm{S}^{-}} \mathrm{CN}$ and $\beta-\mathrm{CN}$, was used as a casein control, and was dissolved to give an equivalent concentration of protein. Gels were stained for $24 \mathrm{~h}$ with Instant Blue Coomassie (Expedeon/Abcam, Cambridge, UK) and scanned using a dual-lens Epson Perfection V700 Photo model J221A with Epson Scan software (Epson Deutschland GmbH, Meerbusch, Germany). The bands were identified as described by McSweeney et al. (1994) and Mooney et al. (1998).

\section{Texture Analysis}

The hardness of each cheese sample was measured after 14, 90, and $180 \mathrm{~d}$ of ripening. Cheese samples were prepared as described by Lamichhane et al. (2018). The texture profile was assessed using a TAHDi analyzer (Stable Micro Systems, Godalming, UK), equipped with a $75-\mathrm{mm}$ (diameter) compression plate and a 50$\mathrm{kg}$ load cell. Each cube was taken from the refrigerator and immediately compressed, in 2 successive bites, to approximately $40 \%$ of its original height at a rate of $1.00 \mathrm{~mm} / \mathrm{s}$ (Henneberry et al., 2015). Hardness was calculated as described by Chevanan et al. (2006).

\section{Statistical Analysis}

The main effects of storage time and protease activity, as well as the interaction between storage time and protease activity, on the parameters measured in the inoculated milk were investigated. The least squares means of those effects were calculated using the GAUSSIAN procedure in SAS 9.3 (SAS Institute Inc., Cary, $\mathrm{NC})$. The fixed effects included in each model were storage time (0 and $48 \mathrm{~h}$ ) and protease activity (C, P1, and $\mathrm{P} 4)$. The containers in which inoculated milk was stored within week were considered the experimental unit. The response variables were N\%, NCN\%, NPN\%, 
and $\mathrm{NCP} \% ; \kappa-\mathrm{CN}, \alpha_{\mathrm{S} 1^{-}} \mathrm{CN}, \alpha_{\mathrm{S}^{-}} \mathrm{CN}, \beta-\mathrm{CN}, \alpha-\mathrm{LA}, \beta-\mathrm{LG}$ $\mathrm{A}$ and $\mathrm{B}$, total casein contents; $\mathrm{pH}$; TBC and PBC.

The influence of those same effects was also investigated on variables measured in the cheeses and whey produced. When the cheeses were considered the experimental unit, the response variables were $\mathrm{Y} \%$, $\% \mathrm{REC}_{\mathrm{FAT}}, \% \mathrm{REC}_{\mathrm{PROT}}$, and composition after $7 \mathrm{~d}$ (fat, protein, moisture, salt, TS, S/M, MNFS, FDM, and $\mathrm{pH})$. When the whey produced was considered the experimental unit, the response variables were fat and protein contents.

Finally, we determined the influence of those same effects and ripening time $(14,90$, and $180 \mathrm{~d})$ on variables measured during the ripening of the cheeses produced (experimental unit). The least squares means of those effects were also calculated using the GAUSSIAN procedure in SAS 9.3 (SAS Institute Inc., Cary, NC). The response variables were $\mathrm{pH}, \mathrm{pH} 4.6-\mathrm{SN} / \mathrm{TN}$, concentrations of FAA, and hardness. For $\mathrm{pH}$, the analysis also included the data measured at $7 \mathrm{~d}$ of ripening. Residual checks were made to ensure that the assumptions of the analyses were met. The Tukey test (at 5\% error probability) was used to compare the means for all variables.

\section{RESULTS}

\section{Milk Composition}

The mean composition parameters and $\mathrm{pH}$ of milk from the different treatments are shown in Table 1, as well as the effects of storage time and protease activity and their interaction.

The mean $( \pm \mathrm{SE}) \% \mathrm{~N}$ decreased significantly with increasing level of protease activity (C: 4.10, P1: 3.94 and P4: $3.91 \pm 0.05 \%$; Table 1). Protease activity also affected the $\% \mathrm{NCN}$ and $\% \mathrm{NCP}$ of milk samples. The variations in those fractions were considered minimal (Table 1).

In relation to casein fractions, results from the statistical analysis indicated that none of the factors significantly affected the level of $\kappa$ - $\mathrm{CN}$; however, numerical decreases in $\kappa$-CN levels with increasing level of protease added were observed (Table 1 ). The mean contents of $\beta-\mathrm{CN}, \alpha-\mathrm{LA}, \beta-\mathrm{LG} \mathrm{A}$ and $\mathrm{B}$ decreased slightly but significantly over storage time (Table 1).

The casein chromatograms of all milk samples, stored for up to $48 \mathrm{~h}$, are shown in Figure 2. The $\beta-\mathrm{CN}$ content decreased with increasing level of protease added. Storage time affected the $\mathrm{pH}$ of the milk samples; however, the decreases observed over time were minimal.

\section{Microbiological Counts in Milk}

The mean TBC and PBC measured at 0 and $48 \mathrm{~h}$ in all milk samples, as well as the effects of storage time, protease activity, and their interaction, are shown in Table 2. The mean TBC increased significantly with protease activity and storage time, whereas $\mathrm{PBC}$ increased significantly with storage time; it is noted that the enzyme preparation used was not pasteurized and so may have contained live cells.

Table 1. Mean $( \pm \mathrm{SE})$ contents of nitrogen fractions, caseins and major whey proteins, and $\mathrm{pH}$, in control (C) milk samples and milk samples with protease activity levels of $0.15(\mathrm{P} 1)$ and $0.60(\mathrm{P} 4) \mathrm{U} / \mathrm{L}$ stored for up to $48 \mathrm{~h}$, and significance of the main effects of storage time (S), protease activity $(\mathrm{P})$, and their interaction

\begin{tabular}{|c|c|c|c|c|c|c|c|c|c|c|}
\hline Component & \multicolumn{6}{|c|}{ Protease activity } & $\mathrm{SE}$ & \multicolumn{3}{|c|}{ Significance } \\
\hline \multicolumn{11}{|c|}{ Nitrogen fractions $^{1}$} \\
\hline$\% \mathrm{~N}$ & 4.17 & 4.20 & 4.01 & 3.87 & 3.90 & 3.93 & 0.09 & 0.80 & 0.04 & 0.68 \\
\hline$\% \mathrm{NCN}$ & 0.14 & 0.14 & 0.14 & 0.14 & 0.15 & 0.15 & 0.004 & 0.39 & 0.04 & 0.89 \\
\hline \multicolumn{11}{|c|}{$\begin{array}{l}\text { Caseins and whey proteins } \\
(\mu \mathrm{g} / \mu \mathrm{L})\end{array}$} \\
\hline$\kappa-\mathrm{CN}$ & 7.68 & 6.97 & 6.75 & 6.35 & 5.97 & 5.82 & 0.34 & 0.09 & 0.06 & 0.56 \\
\hline$\alpha_{\mathrm{S} 2}-\mathrm{CN}$ & 5.15 & 4.72 & 4.61 & 4.50 & 4.82 & 4.63 & 0.20 & 0.30 & 0.42 & 0.12 \\
\hline$\alpha_{\mathrm{S}^{-}} \mathrm{CN}$ & 15.03 & 14.10 & 14.02 & 13.92 & 15.22 & 14.33 & 0.38 & 0.83 & 0.32 & 0.05 \\
\hline$\beta-\mathrm{CN}$ & 15.12 & 14.15 & 14.05 & 12.74 & 14.10 & 11.63 & 0.38 & 0.0002 & 0.05 & 0.05 \\
\hline$\alpha-\mathrm{LA}$ & 1.24 & 1.06 & 1.08 & 1.04 & 1.11 & 1.07 & 0.06 & 0.03 & 0.52 & 0.20 \\
\hline
\end{tabular}

${ }_{1} \% \mathrm{NCN}=$ noncasein nitrogen; $\% \mathrm{NCP}=$ noncasein protein. 

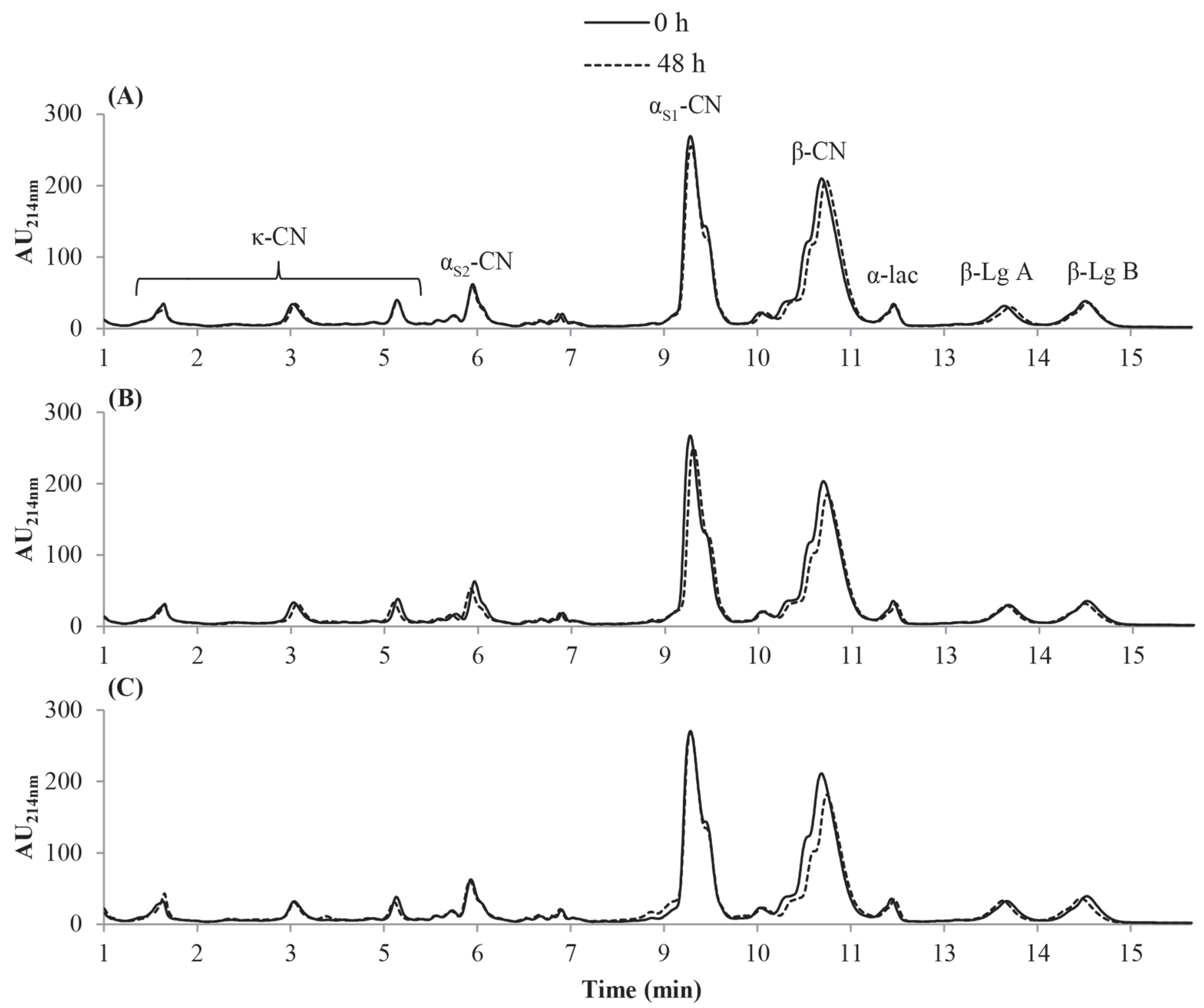

Figure 2. Separation of bovine milk caseins, $\beta$-LG, and $\alpha$-LA by reversed-phase HPLC (measured in absorbance units, AU). Representative chromatograms of (A) control milk samples and samples with protease activity levels of (B) 0.15 and (C) $0.60 \mathrm{U} / \mathrm{L}$ stored for up to $48 \mathrm{~h}$ are shown.

Table 2. Mean $( \pm \mathrm{SE})$ total (TBC) and psychrotrophic (PBC) bacterial counts measured in control (C) milk samples and samples with protease activity levels of $0.15(\mathrm{P} 1)$ and $0.60(\mathrm{P} 4) \mathrm{U} / \mathrm{L}$ stored for up to $48 \mathrm{~h}$, and significance of the main effects of storage time (S), protease activity $(\mathrm{P})$, and the interaction between them

\begin{tabular}{|c|c|c|c|c|c|c|c|c|c|c|}
\hline \multirow{2}{*}{$\begin{array}{l}\text { Bacterial count } \\
\left(\log _{10} \mathrm{cfu} / \mathrm{mL}\right)\end{array}$} & \multicolumn{6}{|c|}{ Protease activity } & \multirow[b]{2}{*}{$\mathrm{SE}$} & \multicolumn{3}{|c|}{ Significance } \\
\hline & $0 \mathrm{~h}$ & $48 \mathrm{~h}$ & $0 \mathrm{~h}$ & $48 \mathrm{~h}$ & $0 \mathrm{~h}$ & $48 \mathrm{~h}$ & & $\mathrm{~S}$ & $\mathrm{P}$ & $\mathrm{S} \times \mathrm{P}$ \\
\hline TBC & 2.21 & 3.27 & 2.41 & 4.32 & 3.41 & 5.00 & 0.34 & $<0.0001$ & 0.04 & 0.13 \\
\hline $\mathrm{PBC}$ & 2.13 & 3.32 & 3.25 & 4.51 & 4.02 & 4.78 & 0.54 & 0.007 & 0.17 & 0.73 \\
\hline
\end{tabular}


Table 3. Mean ( \pm SE) cheese yield $(\mathrm{Y} \%)$, fat recovery (\%REC $\mathrm{FAT})$, and protein recovery $\left(\% \mathrm{REC} \mathrm{CROT}_{\mathrm{PR}}\right)$ measured in control (C) milk samples and samples with protease activity levels of $0.15(\mathrm{P} 1)$ and $0.60(\mathrm{P} 4) \mathrm{U} / \mathrm{L}$ stored for up to $48 \mathrm{~h}$, and significance of the main effects of storage time $(\mathrm{S})$, protease activity $(\mathrm{P})$, and the interaction between them

\begin{tabular}{|c|c|c|c|c|c|c|c|c|c|c|}
\hline \multirow{2}{*}{ Variable } & \multicolumn{6}{|c|}{ Protease activity } & \multirow{2}{*}{$\mathrm{SE}$} & \multicolumn{3}{|c|}{ Significance } \\
\hline & \multicolumn{2}{|c|}{$\mathrm{C}$} & \multicolumn{2}{|c|}{$\mathrm{P} 1$} & \multicolumn{2}{|c|}{$\mathrm{P} 4$} & & S & $\mathrm{P}$ & $\mathrm{S} \times \mathrm{P}$ \\
\hline $\mathrm{Y} \%$ & 11.40 & 11.94 & 11.56 & 11.48 & 11.38 & 11.17 & 0.1 & 0.66 & 0.13 & 0.27 \\
\hline$\% \mathrm{REC}_{\mathrm{FAT}}$ & 86.73 & 85.91 & 86.93 & 85.24 & 86.85 & 85.15 & 0.5 & 0.03 & 0.87 & 0.72 \\
\hline$\% \mathrm{REC}_{\mathrm{PROT}}$ & 72.23 & 70.16 & 76.54 & 75.76 & 70.84 & 70.76 & 1.1 & 0.54 & 0.68 & 0.37 \\
\hline
\end{tabular}

\section{Cheese Yield and Cheese and Whey Composition}

The mean $\mathrm{Y} \%, \% \mathrm{REC}_{\mathrm{FAT}}$, and $\% \mathrm{REC}_{\mathrm{PROT}}$ obtained for all cheeses manufactured after 0 and $48 \mathrm{~h}$ of milk storage are shown in Table 3. Storage time affected the mean $\% \mathrm{REC}_{\mathrm{FAT}}(P=0.03)$, whereas none of the factors affected the mean $\mathrm{Y} \%$ or $\% \mathrm{REC}_{\mathrm{PROT}}$.

The effects of storage time, protease activity, and interaction between those factors on cheese and whey composition are shown in Table 4. Only FDM content was affected by storage time. None of the factors influenced the fat and protein contents in whey.

The mean $( \pm \mathrm{SE}) \mathrm{pH}$ measured in the cheese samples from the different treatments and stored for 7, 14, 90, and $180 \mathrm{~d}$ are shown in Table 5. Ripening time $(P=$ $0.01)$ and treatment $(P<0.001)$ affected the $\mathrm{pH}$ of the cheeses. Storage time $(P=0.05)$ and the interaction between ripening time and storage time $(P=0.96)$, ripening time and treatment $(P=0.99)$, storage time and treatment $(P=0.10)$, and ripening time, storage time, and treatment $(P=0.99)$ did not affect the mean $\mathrm{pH}$ of the samples.

\section{Proteolysis During Cheese Ripening}

The mean \%pH 4.6-SN/TN obtained for cheeses C, $\mathrm{P} 1$, and $\mathrm{P} 4$ throughout ripening time are shown in Table 6. Ripening time affected the mean $\mathrm{N}$ content quantified in those fractions $(P<0.0001)$; however, the level of added protease $(P=0.17)$, storage time $(P=0.71)$, or their interactions did not affect mean $\mathrm{N}$ content.

The concentrations of all FAA increased significantly over ripening time, with the exception of Lys (Table 7). The mean concentrations of the FAA measured in all cheeses after $180 \mathrm{~d}$ of ripening are shown in Figure 3. Leucine and Glu were the most abundant FAA quantified in all cheeses produced using milk stored for 0 and $48 \mathrm{~h}$, with approximately 250 and $235 \mathrm{mg} / \mathrm{kg}$ at 180 d, respectively, followed by Phe, Val, Lys, His, and Pro (approximately 190, 110, 93, 90, and $74 \mathrm{mg} / \mathrm{kg}$ of cheese, respectively).

The peptide peaks obtained for the $\mathrm{pH} 4.6$-soluble fractions of the cheeses at $180 \mathrm{~d}$ of ripening were broadly similar (Figure 4). Differences were observed

Table 4. Mean $( \pm \mathrm{SE})$ composition of cheeses produced using control $(\mathrm{C})$ milk and milk with activity levels of $0.15(\mathrm{P} 1)$ and $0.60(\mathrm{P} 4) \mathrm{U} / \mathrm{L}$, and fat and protein contents in whey obtained during manufacture of Cheddar cheese; and significance of the main effects of storage time (S), protease activity $(\mathrm{P})$ and the interaction between them

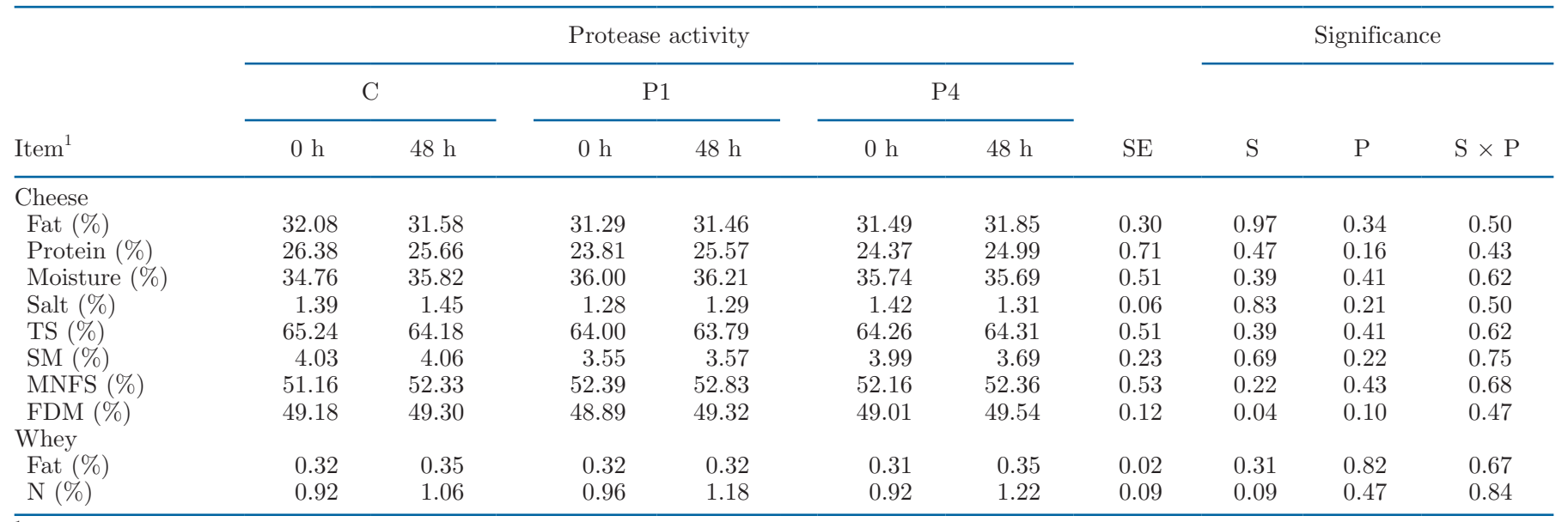

${ }^{1} \mathrm{SM}=$ salt-in-moisture; MNFS $=$ moisture in the nonfat substance; FDM $=$ fat in dry matter. 
Table 5. Mean $( \pm \mathrm{SE}) \mathrm{pH}$ measured throughout ripening of Cheddar cheeses produced using control $(\mathrm{C})$ milk and milk with protease activity levels of $0.15(\mathrm{P} 1)$ and $0.60(\mathrm{P} 4) \mathrm{U} / \mathrm{L}$ and stored for up to $48 \mathrm{~h}$

\begin{tabular}{|c|c|c|c|c|c|}
\hline \multirow{2}{*}{$\begin{array}{l}\text { Protease } \\
\text { activity }\end{array}$} & \multirow{2}{*}{$\begin{array}{l}\text { Time } \\
\text { (h) }\end{array}$} & \multicolumn{4}{|c|}{ Ripening time (d) } \\
\hline & & 7 & 14 & 90 & 180 \\
\hline \multirow[t]{2}{*}{$\mathrm{C}$} & 0 & $5.19 \pm 0.30$ & $5.20 \pm 0.29$ & $5.25 \pm 0.26$ & $5.29 \pm 0.30$ \\
\hline & 48 & $5.05 \pm 0.01$ & $5.08 \pm 0.00$ & $5.11 \pm 0.00$ & $5.15 \pm 0.00$ \\
\hline \multirow[t]{2}{*}{$\mathrm{P} 1$} & 0 & $4.95 \pm 0.01$ & $5.00 \pm 0.05$ & $5.06 \pm 0.05$ & $5.11 \pm 0.05$ \\
\hline & 48 & $5.10 \pm 0.27$ & $5.13 \pm 0.27$ & $5.18 \pm 0.28$ & $5.23 \pm 0.28$ \\
\hline \multirow[t]{2}{*}{$\mathrm{P} 4$} & 0 & $5.17 \pm 0.19$ & $5.18 \pm 0.20$ & $5.20 \pm 0.22$ & $5.25 \pm 0.21$ \\
\hline & 48 & $5.17 \pm 0.26$ & $5.19 \pm 0.30$ & $5.20 \pm 0.28$ & $5.26 \pm 0.26$ \\
\hline
\end{tabular}

in relation to the size of the peptide peaks between samples, indicating possible quantitative, but not qualitative, differences in the levels of proteolysis in terms of relative concentrations of those peptides.

Electrophoresis indicated a progressive increase in the breakdown of $\alpha_{\mathrm{S}_{1}} \mathrm{CN}$ and $\beta-\mathrm{CN}$ throughout ripening (Figure 5). The pattern of proteolysis over ripening was similar between cheeses manufactured using uninoculated and inoculated milk after $0 \mathrm{~h}$ of storage. In contrast, we detected an increase in the breakdown of $\beta$-CN with increasing levels of protease activity in cheeses manufactured using milk stored with enzyme added for $48 \mathrm{~h}$. In addition, the electrophoretogram for sample P4 manufactured after $48 \mathrm{~h}$ of milk storage showed an increase in the intensity of the band denoted by $\mathrm{X}$. This indicates an increase in proteolytic activity in that samples compared with $\mathrm{C}$ and $\mathrm{P} 1$.

Ripening time affected the mean hardness of the cheeses (14 d: 265.9, 90 d: 225.6, 180 d: $127.7 \pm 10.3 \mathrm{~N}$; $P<0.0001$; Table 8). Storage time $(P=0.54)$, protease activity $(P=0.13)$, ripening time $\times$ treatment $(P=$ $0.73)$, storage time $\times$ treatment $(P=0.61)$, and ripening time $\times$ storage time $\times$ treatment $(P=0.98)$ did not affect mean cheese hardness.

\section{DISCUSSION}

Overall, the addition of the Pseudomonas protease after milk pasteurization had an effect both in milk during storage and, to a lesser extent, in cheese during ripening. The concentrations of some caseins decreased in the milk during cold storage with increasing levels of protease activity, indicating that the protease was active during this phase. The addition of protease seemed to have mainly affected the mean $\beta-\mathrm{CN}$ and $\kappa-\mathrm{CN}$ contents in milk over storage time (Table 1 and Figure 2). Differences of approximately 1.5 and $2.0 \mu \mathrm{g} / \mu \mathrm{L}$ in mean $\kappa-C N$ and $\beta-C N$ concentrations, respectively, were observed between samples C and P4. Similarly, Baglinière et al. (2013) reported that a thermoresistant protease (AprX) produced by a $P$. fluorescens strain preferably hydrolyzed $\beta-\mathrm{CN}$ in milk, and Matéos et al. (2015) observed rapid hydrolysis of $\kappa-\mathrm{CN}$ and $\beta-\mathrm{CN}$ in milk in similar proportions by AprX. However, other studies (Zhang et al., 2015, 2018) reported that thermoresistant proteases produced by Pseudomonas strains preferably hydrolyze $\kappa-\mathrm{CN}$ followed by $\beta-\mathrm{CN}$. Those differences in results could be due to the methodology used to investigate hydrolysis or differences in the specificity of the protease isolated. $\beta$-Casein, along with $\alpha_{S}-\mathrm{CN}$, constitutes the basic microstructure of cheese, and their reduced concentrations in milk could affect rennet clotting of milk and curd formation (St-Gelais and Hache, 2005).

In addition, the increase in breakdown of caseins and whey proteins in milk with increasing protease activity over storage time before cheesemaking could have resulted in loss of AA or peptides into whey, which could

Table 6. Mean $( \pm \mathrm{SE})$ levels of $\mathrm{pH}$ 4.6-soluble N/total N (g/100 g) measured during ripening of cheeses produced with control (C) milk and milk with protease activity levels of $0.15(\mathrm{P} 1)$ and $0.60(\mathrm{P} 4) \mathrm{U} / \mathrm{L}$ and stored for up to $48 \mathrm{~h}$

\begin{tabular}{llccc}
\hline & & \multicolumn{3}{c}{ Ripening time (d) } \\
\cline { 3 - 5 } $\begin{array}{l}\text { Protease } \\
\text { activity }\end{array}$ & $\begin{array}{l}\text { Time } \\
\text { (h) }\end{array}$ & 14 & 90 & 180 \\
\hline $\mathrm{C}$ & 0 & $4.68 \pm 1.33$ & $14.74 \pm 1.74$ & $20.55 \pm 0.56$ \\
& 48 & $6.31 \pm 0.23$ & $17.45 \pm 0.32$ & $22.53 \pm 0.56$ \\
P1 & 0 & $5.35 \pm 1.92$ & $16.55 \pm 3.68$ & $22.58 \pm 4.07$ \\
& 48 & $5.58 \pm 0.97$ & $15.97 \pm 1.04$ & $21.35 \pm 0.71$ \\
P4 & 0 & $5.60 \pm 1.24$ & $16.74 \pm 1.70$ & $22.71 \pm 0.66$ \\
& 48 & $5.92 \pm 1.71$ & $15.99 \pm 2.10$ & $22.05 \pm 1.13$ \\
\hline
\end{tabular}


have resulted in the increase in $\% \mathrm{~N}$ in whey samples over time as shown in Table 4 (Emmons et al., 1990; Barbano et al., 1991). We also observed decreases in $\%$ REC $_{\text {PROT }}$ with increasing amount of protease added (Table 3), which could be due to the breakdown of proteins in milk during storage.

The increases in $\mathrm{TBC}$ and $\mathrm{PBC}$ with protease activity and over storage could be due to the P. fluorescens cells in the supernatant (containing protease) used for inoculation; the initial TBC and PBC increased as the amount of supernatant added was increased to achieve the experimental levels of protease activity in the milk samples.

Although the level of protease activity and storage time had little effect on the composition of milk and cheese, the statistical differences observed in the mean $\mathrm{Y} \%, \% \mathrm{REC}_{\mathrm{FAT}}, \% \mathrm{REC}_{\mathrm{PROT}}$, and whey composition were also minimal (Tables 3 and 4). Those results could also indicate that the protease had a low activity when subjected to the processing conditions (e.g., variations in $\mathrm{pH}$ ). In addition, the composition of the cheeses produced was similar to that obtained by Auldist et al. (2016) (moisture: $37.5 \%$, fat: $31 \%$, protein: $25.5 \%$, salt: $1.70 \%$, SM: $4.60 \%$, FDM: $49.5 \%$ ) and reported by Fox et al. (2017) (moisture: $37.2 \%$, protein: $25.4 \%$, fat: $33.1 \%$, salt: $1.80 \%$, SM: $4.8 \%$ ).

The variations in mean $\mathrm{pH}$ between treatments were small. After $7 \mathrm{~d}$ of ripening, the mean $\mathrm{pH}$ of cheeses from each treatment varied from 4.95 to 5.15 , which was within the ranges specified for premium quality Cheddar as defined by Fox (1975) and Pearce and Gilles (1979). The $\mathrm{pH}$ of the cheeses increased by ap- proximately 0.1 unit after $180 \mathrm{~d}$ of ripening, similar to the increase reported by Fox et al. (2004). The increase in $\mathrm{pH}$ during ripening is due to formation of alkaline nitrogenous compounds and catabolism of lactic acid (Fox et al., 2004).

The pattern of proteolysis investigated in each experimental cheese (quantification of $\mathrm{pH} 4.6 \mathrm{SN} / \mathrm{TN}$, concentrations of FAA, peptide profiles, urea-PAGE) indicated that the protease added had minimal effect on proteolysis during ripening.

The quantification of the $\mathrm{pH} 4.6 \mathrm{SN} / \mathrm{TN}$ is a measurement of proteolysis in cheeses, because this fraction contains the peptides resulting from casein breakdown (Hou et al., 2014). The magnitude of the increase in $\mathrm{pH}$ 4.6 SN/TN over ripening (from approximately $5.0 \%$ at $14 \mathrm{~d}$ to $22.0 \%$ at $180 \mathrm{~d}$; Table 6 ) was similar between all cheeses and in agreement with previous reports for Cheddar cheese (Fenelon et al., 2000a; Wang et al., 2011; Hou et al., 2014). The progressive breakdown of the casein matrix during ripening also increases concentrations of FAA (Fox and McSweeney, 1996), as was observed in all samples of pH4.6-SN extracts of cheese in this study (Figure 3). Fenelon et al. (2000b) and McCarthy et al. (2017) also observed high levels of Glu, His, Leu, Lys, Phe, Pro, and Val in Cheddar cheeses.

Storage time did not affect the concentrations of each FAA in cheese; however, we observed some trends in relation to ripening and protease activity. Cheeses $\mathrm{P} 1$ and $\mathrm{P} 4$, which were produced using milk stored for $48 \mathrm{~h}$, had higher concentrations of Ala, Glu, Gly, Ile, Leu, Lys, Met, Pro, and Val than the control cheeses. These increases in proteolysis in the $\mathrm{P} 1$ and $\mathrm{P} 4$ cheeses

Table 7. Significance of the main effects of storage time (S), protease activity $(\mathrm{P})$, ripening time (R), and their interactions on the content of free AA contents $(\mathrm{mg} / \mathrm{kg}$ of cheese) measured in the $\mathrm{pH}$ 4.6-soluble fractions of control cheese samples and cheeses manufactured with milk containing 0.15 or $0.60 \mathrm{U} / \mathrm{L}$ of protease activity

\begin{tabular}{|c|c|c|c|c|c|c|}
\hline \multirow{2}{*}{$\begin{array}{l}\mathrm{AA} \\
(\mathrm{mg} / \mathrm{kg})\end{array}$} & \multicolumn{6}{|c|}{ Significance } \\
\hline & S & $\mathrm{P}$ & $\mathrm{R}$ & $\mathrm{S} \times \mathrm{P}$ & $\mathrm{R} \times \mathrm{P}$ & $\mathrm{S} \times \mathrm{P} \times \mathrm{R}$ \\
\hline Asp & 0.21 & 0.52 & 0.0007 & 0.26 & 0.60 & 0.27 \\
\hline Thr & 0.60 & 0.49 & 0.002 & 0.37 & 0.24 & 0.13 \\
\hline Ser & 0.54 & 0.67 & 0.01 & 0.39 & 0.67 & 0.59 \\
\hline Glu & 0.85 & 0.84 & 0.03 & 0.28 & 0.92 & 0.34 \\
\hline Gly & 0.91 & 0.83 & 0.02 & 0.37 & 0.59 & 0.21 \\
\hline Ala & 0.77 & 0.81 & 0.006 & 0.36 & 0.33 & 0.11 \\
\hline Cys & 0.11 & 0.18 & $<0.0001$ & 0.95 & 0.74 & 0.89 \\
\hline Val & 0.96 & 0.86 & 0.008 & 0.34 & 0.58 & 0.19 \\
\hline Met & 0.98 & 0.82 & 0.0002 & 0.32 & 0.65 & 0.18 \\
\hline Ile & 0.60 & 0.89 & 0.007 & 0.11 & 0.81 & 0.64 \\
\hline Leu & 0.64 & 0.94 & $<0.0001$ & 0.09 & 0.80 & 0.47 \\
\hline Tyr & 0.20 & 0.20 & $<0.0001$ & 0.50 & 0.45 & 0.85 \\
\hline Phe & 0.60 & 0.47 & $<0.0001$ & 0.55 & 0.40 & 0.77 \\
\hline His & 0.41 & 0.54 & $<0.0001$ & 0.25 & 0.59 & 0.70 \\
\hline Lys & 0.80 & 0.95 & 0.07 & 0.45 & 0.67 & 0.18 \\
\hline Trp & 0.30 & 0.73 & $<0.0001$ & 0.19 & 0.71 & 0.69 \\
\hline Arg & 0.31 & 0.32 & $<0.0001$ & 0.51 & 0.50 & 0.83 \\
\hline Pro & 0.21 & 0.52 & 0.0007 & 0.26 & 0.60 & 0.27 \\
\hline
\end{tabular}


could be related to the increase in bacterial counts with protease activity that was observed in milk samples. Bacterial cells that remained in the milk after pasteurization or Pseudomonas cells that were present in the supernatant could have contributed to an increased concentration of enzymes in milk during storage, increasing the proteolytic activity in the cheese produced with that milk. Concentrations of FAA are associated with the development of flavor in cheese (Fox et al., 2017), and the prolonged storage of milk containing high levels of proteolytic bacteria could affect the sensory quality of the product.

Urea-PAGE electrophoretograms showed a slight increase in proteolysis in $\mathrm{P} 4$ cheese samples manufactured after $48 \mathrm{~h}$ of milk storage; the increase in intensity of band $\mathrm{X}$, above $\beta-\mathrm{CN}$, was greater in $\mathrm{P} 4$ cheeses compared with samples $\mathrm{C}$ and $\mathrm{P} 1$ (Figure 5). Furthermore, the proteolysis patterns of all samples of cheese pH4.6SN extracts were similarly independent of the level of protease activity. During ripening, $\alpha_{S^{-}} \mathrm{CN}$ is degraded more extensively than $\beta$-CN into smaller fragments by proteolytic enzymes (St-Gelais and Hache, 2005), as we also observed in the electrophoretograms.

In a previous study, we observed that the protease (or proteases) tested potentially has a specificity similar to that of chymosin in relation to casein hydrolysis (Paludetti et al., 2020). This could explain the similarity between the peptide peaks obtained for control cheese
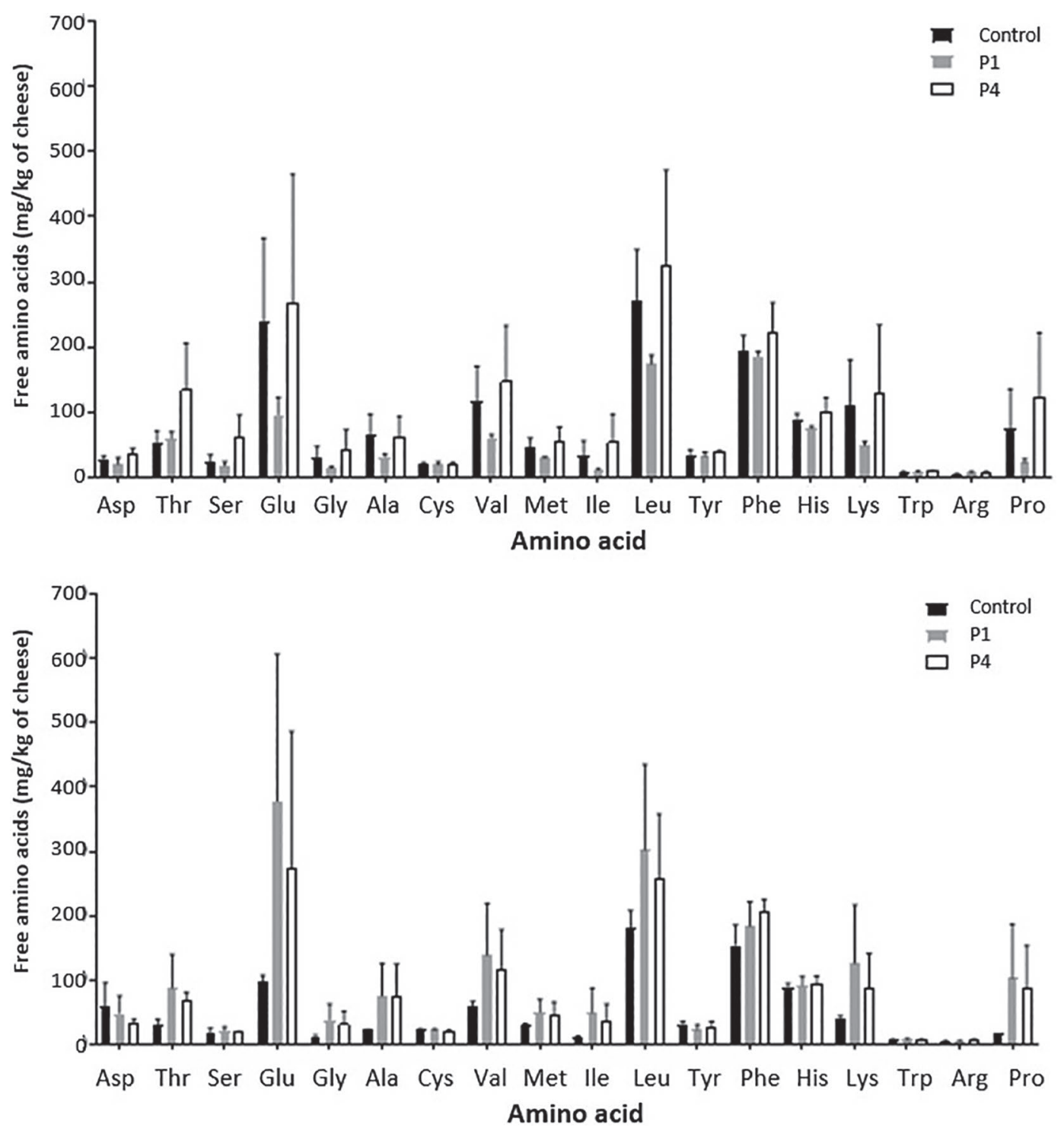

Figure 3. The effect of milk treatments on the mean levels of individual free AA in $\mathrm{pH} 4.6$-soluble $\mathrm{N}$ extracts from Cheddar cheeses at 180 $\mathrm{d}$ of ripening. Cheeses were produced after (A) $0 \mathrm{~h}$ and (B) $48 \mathrm{~h}$ of storage using control milk or milk inoculated with 0.15 (P1) and 0.60 (P4) $\mathrm{U} / \mathrm{L}$ protease. Data presented are means of data from 3 replicate trials. Error bars show the SEM from 3 replicate trials. 


\section{(A)}

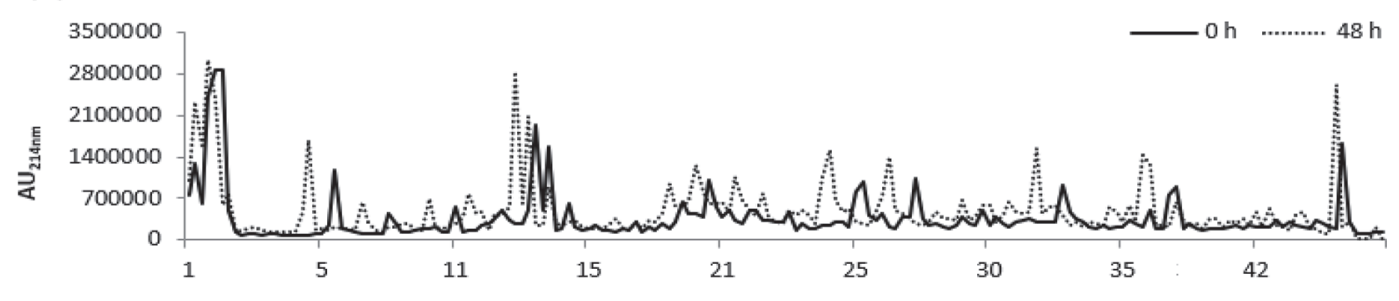

(B)

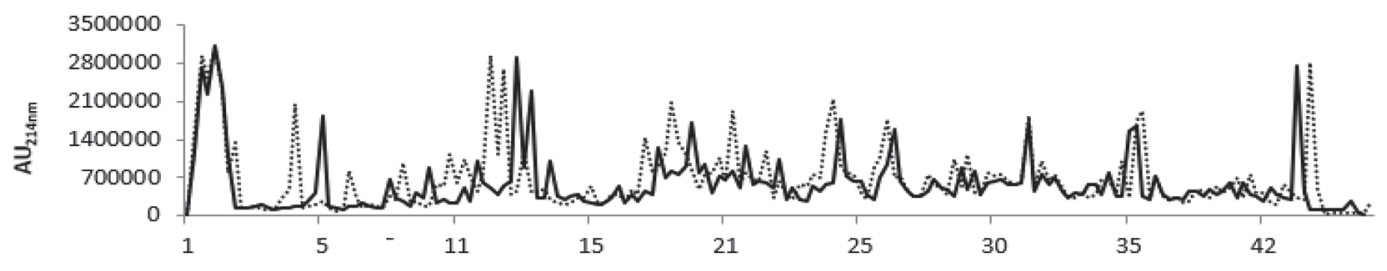

(C)

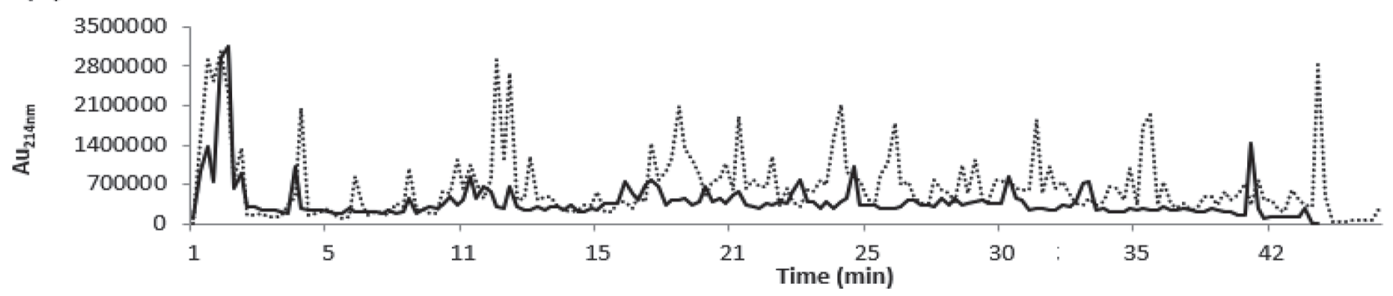

Figure 4. Representative reversed-phase ultra-performance liquid chromatography profiles of peptides in the $\mathrm{pH} 4.6$-soluble fraction of Cheddar cheeses manufactured using milk with protease activity levels of (A) 0 (control), (B) 0.15 , and (C) $0.60 \mathrm{U} / \mathrm{L}$, after 0 and $48 \mathrm{~h}$ of storage, at $180 \mathrm{~d}$ of ripening.

samples and samples with added protease(s) at $180 \mathrm{~d}$ of ripening (Figure 4). In addition, the decrease in some of the peptide peaks could indicate that those could have been further hydrolyzed by the protease during ripening.

Proteolysis is a determining factor of the final texture and flavor in cheeses (Fox et al., 2017). Because levels of proteolysis were similar between samples, it is perhaps not surprising that the mean hardness values obtained for cheeses from each treatment were similar. The softening of cheese texture during ripening is a result of the hydrolysis of the casein matrix, solubilization of calcium in the early stages of ripening, and a decrease in the water activity of the curd (McSweeney, 2004; Fox et al., 2017). The latter occurs as a consequence of changes in water-binding by the carboxylic acid and amino groups formed on hydrolysis. Therefore, as expected, the hardness of the cheese samples decreased over ripening time. The chemical composition of cheese (e.g., fat and moisture content) can also affect the hardness of cheese during ripening. In addition, as reported by Lamichhane et al. (2019), hydrolysis of $\alpha_{S^{-}}$and $\beta-C N$ influences the fracture stress and strain of cheeses, respectively. The decreases in hardness between 14 and $180 \mathrm{~d}$ of ripening (approximately $100 \mathrm{~N}$ ) observed in this study were similar to those reported by McCarthy et al. (2016) and Hickey et al. (2018) for Cheddar-style cheeses.

Finally, the results suggested that the protease was not extensively active in the Cheddar cheese matrix. An azocasein test was carried out, as described by Paludetti et al. (2020), to investigate whether the protease was transferred into the whey during manufacture of each cheese. The results of the test were not significantly different $(0 \mathrm{~h} ; \mathrm{C}: 0.065 \pm 0.064 \mathrm{~nm}, \mathrm{P} 5: 0.075$ $\pm 0.066 \mathrm{~nm}, \mathrm{P} 20: 0.092 \pm 0.095 \mathrm{~nm} ; 48 \mathrm{~h}, \mathrm{C}: 0.095 \pm$ $0.119 \mathrm{~nm}, \mathrm{P} 5: 0.174 \pm 0.045 \mathrm{~nm}, \mathrm{P} 20: 0.147 \pm 0.205$ $\mathrm{nm} ; P>0.05)$, indicating that the protease remained in the cheese matrix. The activity of thermoresistant proteases produced by Pseudomonas bacteria is optimal at a $\mathrm{pH}$ between 7 and 9 and in a temperature range of 30 to $45^{\circ} \mathrm{C}$ (Martins et al., 2015). Therefore, the low $\mathrm{pH}$ and storage temperature of the cheeses could have affected protease activity. Other cheese types are characterized by higher ripening temperatures and $\mathrm{pH}$, such as Swiss cheese (stored at approximately $22^{\circ} \mathrm{C}$ for 4 to $6 \mathrm{wk}$ ), Mozzarella cheese (heated to $57^{\circ} \mathrm{C}$ during stretching), and surface mold-ripened cheeses (e.g., Camembert of pH 7.0; Fox et al., 2017), and may be 


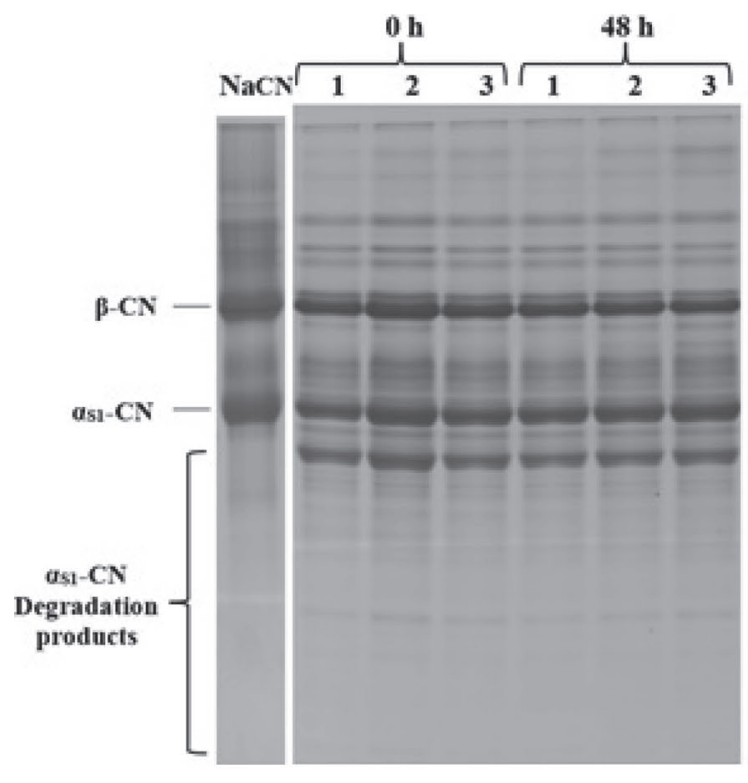

$14 \mathrm{~d}$
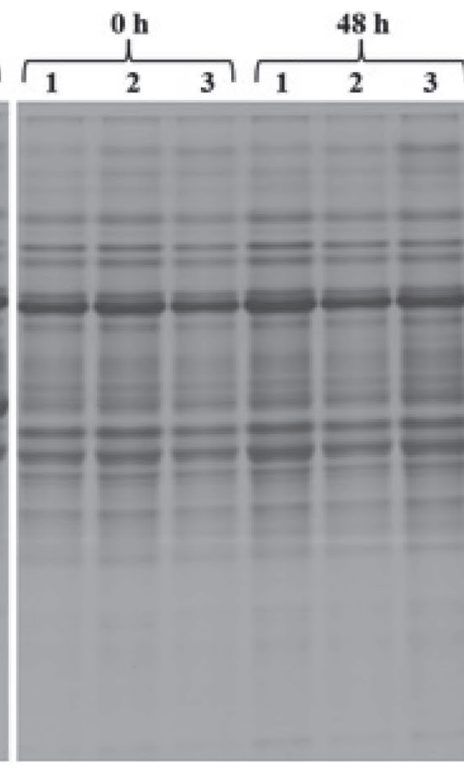

$90 \mathrm{~d}$
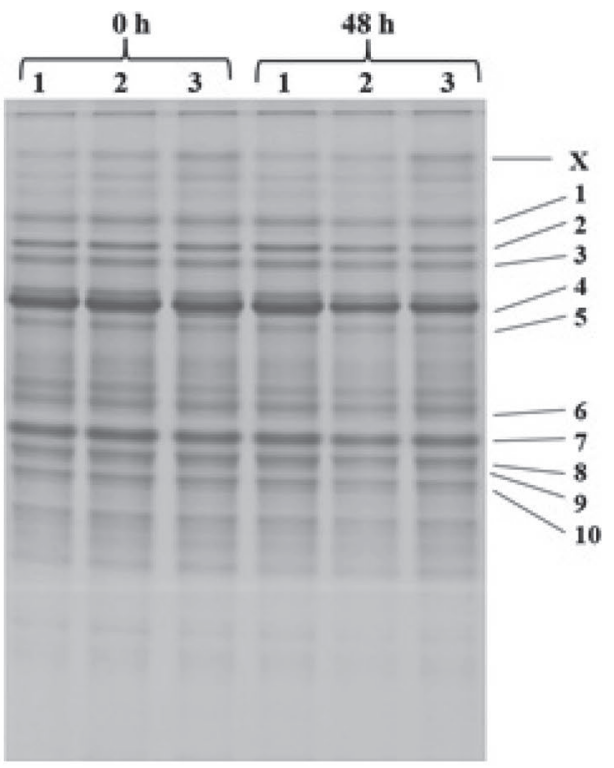

$180 \mathrm{~d}$

Figure 5. Urea-polyacrylamide gel electrophoretograms of Cheddar cheeses stored for 14, 90, and $180 \mathrm{~d}$. Cheeses were produced using control (C) milk or milk inoculated with $0.15(\mathrm{P} 1)$ and $0.60(\mathrm{P} 4) \mathrm{U} / \mathrm{L}$ protease (lanes 1, 2, and 3, respectively) after 0 and $48 \mathrm{~h}$ of storage. Sodium caseinate (lane $\mathrm{NaCN}$ ), loaded at an equivalent weight of protein $(4.75 \mathrm{mg}$ per lane) was included as an unhydrolyzed casein control. Protein bands were identified according to Mooney et al. (1998) and McSweeney et al. (1994): $1=\beta-\mathrm{CN} f(106-209)(\gamma 2) ; 2=\beta-\mathrm{CN} f(29-209)(\gamma 1) ; 3=$

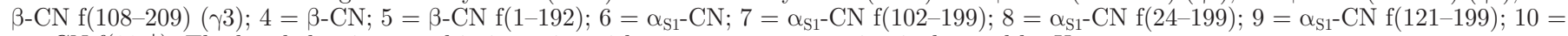
$\alpha_{\mathrm{S1}^{-}} \mathrm{CN} \mathrm{f}\left(33^{-}\right)$. The band that increased in intensity with protease concentration is denoted by $\mathrm{X}$.

more significantly affected if protease is active in the matrix.

\section{CONCLUSIONS}

The levels of activity of the Pseudomonas protease or proteases tested had a minimal effect on proteolysis levels in milk and Cheddar cheese produced. Processing and storage conditions of milk and cheese could have influenced the activity of the protease; consequently, the manufacture and quality of the Cheddar cheeses produced were not affected. Independent of the protease activity level, the composition and levels of proteolysis during ripening in all cheeses were similar and as expected. The levels of protease activity tested did not affect the quality of whey, a valuable by-product obtained in cheese manufacture. Therefore, the levels of psychrotrophic bacterial protease(s) tested in milk during storage did not contribute to increased proteolysis in Cheddar cheese. However, levels of proteolytic activity in milk that are higher than those tested in this study could affect proteolysis in cheese during ripening. Other cheese types are characterized by higher ripening temperatures and $\mathrm{pH}$, and may be more significantly affected if the protease is active in the matrix. Further studies may be necessary to determine the effects of higher protease concentrations, as well as their effects on other cheese types.

Table 8. Mean $( \pm \mathrm{SE})$ hardness $(\mathrm{N})$ measured during ripening of Cheddar cheeses produced with control $(\mathrm{C})$ milk and milk with protease activity levels of $0.15(\mathrm{P} 1)$ and $0.60(\mathrm{P} 4) \mathrm{U} / \mathrm{L}$ stored for up to $48 \mathrm{~h}$

\begin{tabular}{llccc}
\hline & & \multicolumn{3}{c}{ Ripening time $(\mathrm{d})$} \\
\cline { 3 - 5 } $\begin{array}{l}\text { Protease } \\
\text { activity }\end{array}$ & $(\mathrm{h})$ & 14 & 90 & 180 \\
\hline $\mathrm{C}$ & 0 & $258.7 \pm 51.7$ & $226.5 \pm 88.6$ & $121.2 \pm 28.0$ \\
& 48 & $225.1 \pm 51.8$ & $211.0 \pm 16.0$ & $108.1 \pm 13.6$ \\
$\mathrm{P} 1$ & 0 & $248.5 \pm 76.4$ & $210.4 \pm 48.7$ & $122.6 \pm 40.4$ \\
& 48 & $242.0 \pm 90.1$ & $221.6 \pm 33.0$ & $119.1 \pm 13.4$ \\
P4 & 0 & $281.9 \pm 97.5$ & $225.1 \pm 43.4$ & $127.6 \pm 19.7$ \\
& 48 & $314.8 \pm 125.0$ & $244.9 \pm 43.1$ & $134.7 \pm 36.0$ \\
\hline
\end{tabular}




\section{ACKNOWLEDGMENTS}

The authors acknowledge funding (MKLS6643) from the Dairy Research Levy Fund administered by Dairy Research Ireland. Lizandra Paludetti was in receipt of a Teagasc Walsh Fellowship (Ref: 2015045). The authors acknowledge Bernard Corrigan for the guidance in the HPLC analysis and electrophoresis, and also Xiaofeng Xia, Prabin Lamichhane, and Prateek Sharma (Teagasc Food Research Centre, Moorepark, Fermoy, County Cork, Ireland) for all the guidance with cheese manufacture and analysis. The authors have not stated any conflicts of interest.

\section{REFERENCES}

Auldist, M. J., J. S. Greenwood, M. M. Wright, M. Hannah, R. P. W. Williams, P. J. Moate, and W. J. Wales. 2016. Incorporating mixed rations and formulated grain mixes into the diet of grazing cows: Effects on milk composition and coagulation properties, and the yield and quality of Cheddar cheese. J. Dairy Sci. 99:41964205. https://doi.org/10.3168/jds.2015-10428.

Baglinière, F., A. Mateos, G. Tanguy, J. Jardin, V. Briard-Bion, F. Rousseau, B. Robert, E. Beaucher, J. L. Gaillard, C. Amiel, G. Humbert, A. Dary, and F. Gaucheron. 2013. Proteolysis of ultrahigh temperature-treated casein micelles by AprX enzyme from Pseudomonas fluorescens $F$ induces their destabilisation. Int. Dairy J. 31:55-61. https://doi.org/10.1016/j.idairyj.2013.02.011.

Barbano, D. M., R. R. Rasmussen, and J. M. Lynch. 1991. Influence of milk somatic cell count and milk age on cheese yield. J. Dairy Sci. 74:369-388. https://doi.org/10.3168/jds.S0022-0302(91)78179-4.

Boulares, M., M. Mankai, and M. Hassouna. 2011. Effect of activating lacto-peroxidase system in cheese milk on the quality of SaintPaulin cheese. Int. J. Dairy Technol. 64:75-83. https://doi.org/10 .1111/j.1471-0307.2010.00646.x.

British Standards Institution. 1976. Methods for chemical analysis of cheese. Determination of $\mathrm{pH}$ value. BS 770: part 5. British Standard Institution, London, UK.

Caldera, L., L. Franzetti, E. Van Coillie, P. De Vos, P. Stragier, J. De Block, and M. Heyndrickx. 2016. Identification, enzymatic spoilage characterization and proteolytic activity quantification of Pseudomonas spp. isolated from different foods. Food Microbiol. 54:142-153. https://doi.org/10.1016/j.fm.2015.10.004.

Cartwright, G., B. H. McManus, T. P. Leffler, and C. R. Moser. 2005. Rapid determination of moisture/ solids and fat in dairy products by microwave and nuclear magnetic resonance analysis. J. AOAC Int. 88:107-120. https://doi.org/10.1093/jaoac/88.1.107.

Chevanan, N., K. Muthukumarappan, P. Upreti, and L. E. Metzger. 2006. Effect of calcium and phosphorus, residual lactose and saltto-moisture ratio on textural properties of Cheddar cheese during ripening. J. Texture Stud. 37:711-730. https://doi.org/10.1111/j $.1745-4603.2006 .00080 . x$.

Decimo, M., S. Morandi, T. Silvetti, and M. Brasca. 2014. Characterization of gram-negative psychrotrophic bacteria isolated from Italian bulk tank milk. J. Food Sci. 79:M2081-M2090. https://doi .org/10.1111/1750-3841.12645.

Emmons, D. B., D. C. Beckett, and M. Binns. 1990. Milk-clotting enzymes -1 . Proteolysis during cheese making in relation to estimated losses of yield. J. Dairy Sci. 73:2007-2015. https://doi.org/ 10.3168/jds.S0022-0302(90)78879-0.

Ercolini, D., F. Russo, I. Ferrocino, and F. Villani. 2009. Molecular identification of mesophilic and psychrotrophic bacteria from raw cow's milk. Food Microbiol. 26:228-231. https://doi.org/10.1016/ j.fm.2008.09.005.

Fenelon, M. A., and T. P. Guinee. 2000. Primary proteolysis and textural changes during ripening in Cheddar cheeses manufactured to different fat contents. Int. Dairy J. 10:151-158. https://doi.org/10 .1016/S0958-6946(00)00040-6.

Fenelon, M. A., T. P. Guinee, C. Delahunty, J. Murray, and F. Crowe. 2000a. Composition and sensory attributes of retail Cheddar cheese with different fat contents. J. Food Compos. Anal. 13:13-26. https: //doi.org/10.1006/jfca.1999.0844.

Fenelon, M. A., P. O'Connor, and T. P. Guinee. 2000b. The effect of fat content on the microbiology and proteolysis in Cheddar cheese during ripening. J. Dairy Sci. 83:2173-2183. https://doi.org/10 $.3168 /$ jds.S0022-0302(00)75100-9.

Fox, P. F. 1975. Influence of cheese composition on quality. Ir. J. Agric. Food Res. 14:33-42.

Fox, P. F. 1989. Proteolysis during cheese manufacture and ripening. J. Dairy Sci. 72:1379-1400. https://doi.org/10.3168/jds.S0022 -0302(89)79246-8.

Fox, P. F., T. P. Guinee, T. M. Cogan, and P. H. McSweeney. 2017. Fundamentals of Cheese Science. 2nd ed. Springer, New York, NY.

Fox, P. F., and P. L. H. McSweeney. 1996. Proteolysis in cheese during ripening. Food Rev. Int. 12:457-509. https://doi.org/10.1080/ 87559129609541091.

Fox, P. F., P. L. H. McSweeney, T. M. Cogan, and T. P. Guinee. 2004. Cheese: Chemistry, Physics and Microbiology. Vol. 1. 3rd ed. Elsevier Academic Press, London, UK.

Henneberry, S., M. Wilkinson, K. Kilcawley, P. Kelly, and T. Guinee. 2015. Interactive effects of salt and fat reduction on composition, rheology and functional properties of mozzarella-style cheese. Dairy Sci. Technol. 95:613-638. https://doi.org/10.1007/s13594 -015-0231-8.

Hickey, C. D., M. G. O'Sullivan, J. Davis, D. Scholz, K. N. Kilcawley, M. G. Wilkinson, and J. J. Sheehan. 2018. The effect of buttermilk or buttermilk powder addition on functionality, textural, sensory and volatile characteristics of Cheddar-style cheese. Food Res. Int. 103:468-477. https://doi.org/10.1016/j.foodres.2017.09.081.

Hou, J., P. L. H. McSweeney, T. P. Beresford, and T. P. Guinee. 2014. Effect of curd washing on the properties of reduced-calcium and standard-calcium Cheddar cheese. J. Dairy Sci. 97:5983-5999. https://doi.org/10.3168/jds.2014-8051.

IDF. 1982. Determination of the total solids content (cheese and processed cheese). Standard 4a. International Dairy Federation (IDF), Brussels, Belgium.

IDF. 1986. Determination of the nitrogen content (Kjeldahl method) and calculation of crude protein content. Standard 20A. International Dairy Federation (IDF), Brussels, Belgium.

IDF. 1988. Cheese and processed cheese: Determination of chloride content (potentiometric titration method). Standard 88a. International Dairy Federation (IDF), Brussels, Belgium.

IDF. 1993. Milk: Determination of the nitrogen content (Kjeldahl method) and calculation of crude protein content. Standard 20b. International Dairy Federation (IDF), Brussels, Belgium.

IDF. 2001. Milk: Determination of Nitrogen Content-Part 4: Block Digestion Method (Semi-micro Rapid Routine Method). Standard 20-4. International Dairy Federation (IDF), Brussels, Belgium.

IDF. 2004a. Milk: Determination of Nitrogen Content-Part 3: Block Digestion Method (Semi-micro Rapid Routine Method). Standard 20-3. International Dairy Federation (IDF), Brussels, Belgium.

IDF. 2004b. Milk: Determination of Casein-Nitrogen Content-Part 1: Indirect Method (Reference Method). Standard 29-1. International Dairy Federation (IDF), Brussels, Belgium.

IDF. 2008. Skimmed milk, whey and buttermilk-Determination of fat content-Gravimetric method (Reference method). Standard 22. International Dairy Federation (IDF), Brussels, Belgium.

Laird, D. T., S. A. Gambrel-Lenarz, F. M. Scher, T. E. Graham, and R. Reddy. 2004. Microbiological count methods. Pages 153-186 in Standard Methods for the Examination of Dairy Products. 17th ed. H. M. Wehr and J. F. Frank, ed. American Public Health Association, Washington, DC.

Lamichhane, P., A. L. Kelly, and J. J. Sheehan. 2018. Effect of milk centrifugation and incorporation of high-heat-treated centrifugate on the composition, texture, and ripening characteristics of Maasdam cheese. J. Dairy Sci. 101:5724-5737. https://doi.org/10.3168/ jds.2017-14178. 
Lamichhane, P., P. Sharma, D. Kennedy, A. L. Kelly, and J. J. Sheehan. 2019. Microstructure and fracture properties of semi-hard cheese: Differentiating the effects of primary proteolysis and calcium solubilization. Food Res. Int. 125:108525. https://doi.org/10 .1016/j.foodres.2019.108525.

Leighton, T. J., R. H. Dor, R. A. Warren, and R. A. Kelln. 1973. The relationship of serine protease activity to RNA polymerase modification and sporulation in Bacillus subtilis. J. Mol. Biol. 76:103122. https://doi.org/10.1016/0022-2836(73)90083-1.

Mankai, M., M. Boulares, O. Ben Moussa, R. Karoui, and M. Hassouna. 2012. The effect of refrigerated storage of raw milk on the physicochemical and microbiological quality of Tunisian semihard Gouda-type cheese during ripening. Int. J. Dairy Technol. 65:250259. https://doi.org/10.1111/j.1471-0307.2012.00822.x.

Marchand, S., G. Vandriesche, A. Coorevits, K. Coudijzer, V. De Jonghe, K. Dewettinck, P. De Vos, B. Devreese, M. Heyndrickx, and J. De Block. 2009. Heterogeneity of heat-resistant proteases from milk Pseudomonas species. Int. J. Food Microbiol. 133:68-77. https://doi.org/10.1016/j.ijfoodmicro.2009.04.027.

Martins, M. L., U. M. Pinto, K. Riedel, and M. C. D. Vanetti. 2015. Milk-deteriorating exoenzymes from Pseudomonas fluorescens 041 isolated from refrigerated raw milk. Braz. J. Microbiol. 46:207217. https://doi.org/10.1590/S1517-838246120130859.

Mateo, M. J., D. J. O'Callaghan, C. D. Everard, M. Castillo, F. A. Payne, and C. P. O'Donnell. 2010. Evaluation of on-line optical sensing techniques for monitoring curd moisture content and solids in whey during syneresis. Food Res. Int. 43:177-182. https://doi .org/10.1016/j.foodres.2009.09.023.

Matéos, A., M. Guyard-Nicodeme, F. Bagliniere, J. Jardin, F. Gaucheron, A. Dary, G. Humbert, and J. L. Gaillard. 2015. Proteolysis of milk proteins by AprX, an extracellular protease identified in Pseudomonas LBSA1 isolated from bulk raw milk, and implications for the stability of UHT milk. Int. Dairy J. 49:78-88. https:/ /doi.org/10.1016/j.idairyj.2015.04.008.

McAuliffe, L. N. 2017. Role of calcium equilibrium in modulating the textural and functional properties of brine-salted cheese. Chapter 6: Chymosin-mediated proteolysis, calcium solubilization and texture development during the ripening of Gouda-type cheese. Doctoral Diss. University College Cork, Ireland.

McCarthy, C. M., M. G. Wilkinson, and T. P. Guinee. 2017. Effect of coagulant type and level on the properties of half-salt, half-fat Cheddar cheese made with or without adjunct starter: Improving texture and functionality. Int. Dairy J. 75:30-40. https://doi.org/ 10.1016/j.idairyj.2017.07.006.

McCarthy, C. M., M. G. Wilkinson, P. M. Kelly, and T. P. Guinee. 2016. Effect of salt and fat reduction on proteolysis, rheology and cooking properties of Cheddar cheese. Int. Dairy J. 56:74-86. https://doi.org/10.1016/j.idairyj.2016.01.001.

McSweeney, P. L. H. 2004. Biochemistry of cheese ripening. Int. J. Dairy Technol. 57:127-144. https://doi.org/10.1111/j.1471-0307 .2004.00147.x.

McSweeney, P. L. H., S. Pochet, P. F. Fox, and A. Healy. 1994. Partial identification of peptides from the water-insoluble fraction of Cheddar cheese. J. Dairy Res. 61:587-590. https://doi.org/10 $.1017 /$ S0022029900028533.

Mooney, J. S., P. F. Fox, A. Healy, and J. Leaver. 1998. Identification of the principal ater-insoluble peptides in Cheddar cheese. Int. Dairy J. 8:813-818. https://doi.org/10.1016/S0958-6946(98)00116 -2 .

Mounsey, J. S., and B. T. O'Kennedy. 2009. Stability of $\beta$-lactoglobulin/ micellar casein mixtures on heating in simulated milk ultrafiltrate at pH 6.0. Int. J. Dairy Technol. 62:493-499. https://doi.org/10 $.1111 /$ j.1471-0307.2009.00522.x.

Paludetti, L. F., K. Jordan, A. L. Kelly, and D. Gleeson. 2018b. Evaluating the effect of storage conditions on milk microbiological qual- ity and composition. Ir. J. Agric. Food Res. 57:52-62. https://doi .org/10.1515/ijafr-2018-0006.

Paludetti, L. F., A. L. Kelly, and D. Gleeson. 2020. Effect of thermoresistant protease of Pseudomonas fluorescens on rennet coagulation properties and proteolysis of milk. J. Dairy Sci. 103:4043-4055. https://doi.org/10.3168/jds.2019-17771.

Paludetti, L. F., A. L. Kelly, B. O'Brien, K. Jordan, and D. Gleeson. 2018a. The effect of different precooling rates and cold storage on milk microbiological quality and composition. J. Dairy Sci. 101:1921-1929. https://doi.org/10.3168/jds.2017-13668.

Pearce, K. N., and J. Gilles. 1979. Composition and grade of Cheddar cheese manufactured over three seasons. New Zeal. J. Dairy Sci. 14:63-71.

Ribeiro Júnior, J. C., A. M. de Oliveira, F. G. Silva, R. Tamanini, A. L. M. de Oliveira, and V. Beloti. 2018. The main spoilagerelated psychrotrophic bacteria in refrigerated raw milk. J. Dairy Sci. 101:75-83. https://doi.org/10.3168/jds.2017-13069.

Sheehan, J. J., M. A. Fenelon, M. G. Wilkinson, and P. L. H. McSweeney. 2007. Effect of cook temperature on starter and non-starter lactic acid bacteria viability, cheese composition and ripening indices of a semi-hard cheese manufactured using thermophilic cultures. Int. Dairy J. 17:704-716. https://doi.org/10.1016/j.idairyj .2006.08.011.

Sheehan, J. J., and T. P. Guinee. 2004. Effect of pH and calcium level on the biochemical, textural and functional properties of reducedfat mozzarella cheese. Int. Dairy J. 14:161-172. https://doi.org/10 .1016/S0958-6946(03)00167-5.

Sørhaug, T., and L. Stepaniak. 1997. Psychrotrophs and their enzymes in milk and dairy products: quality aspects. Trends Food Sci. Technol. 8:35-41. https://doi.org/10.1016/S0924-2244(97)01006-6.

St-Gelais, D., and S. Hache. 2005. Effect of $\beta$-casein concentration in cheese milk on rennet coagulation properties, cheese composition and cheese ripening. Food Res. Int. 38:523-531. https://doi.org/10 .1016/j.foodres.2004.11.006.

Tye, T. M., N. F. Haard, and T. R. Patel. 1988. Effects of bacterial protease on the quality of Cheddar cheese. Can. Inst. Food Sci. Technol. J. 21:373-377. https://doi.org/10.1016/S0315 -5463(88)70971-2.

Wang, F., X. Zhang, J. Luo, H. Guo, S. S. Zeng, and F. Ren. 2011. Effect of proteolysis and calcium equilibriu, on functional properties of natural Cheddar cheese during ripening and the resultant processed cheese. J. Food Sci. 76:E248-E253. https://doi.org/10 .1111/j.1750-3841.2011.02085.x.

Wehr, H. M., and J. F. Frank. 2004. Standard Methods for the Examination of Dairy Products. 17th ed. American Public Health Association, Washington, DC.

Zhang, C., E. Bijl, and K. Hettinga. 2018. Destabilization of UHT milk by protease AprX from Pseudomonas fluorescens and plasmin. Food Chem. 263:127-134. https://doi.org/10.1016/j.foodchem .2018.04.128.

Zhang, S., H. Li, H. Uluko, L. Liu, X. Pang, and J. Lv. 2015. Investigation of protease production by Pseudomonas fluorescens BJ10 and degradation on milk proteins. J. Food Process. Preserv. 39:2466-2472. https://doi.org/10.1111/jfpp.12496.

\section{ORCIDS}

Lizandra F. Paludetti @ https://orcid.org/0000-0002-8672-4522 Tom F. O'Callaghan (ㄴ) https://orcid.org/0000-0003-2684-7253 Jeremiah J. Sheehan @ https://orcid.org/0000-0003-1742-2827 David Gleeson ๑ https://orcid.org/0000-0003-3064-3632 Alan L. Kelly @ https://orcid.org/0000-0003-2759-1587 